International Research Journal of Materials Sciences and Applications
(ISSN:2575-1034)

\title{
Eutectic Carbides in Damascus steel Ledeburite Class (Wootz)
}

\section{D.A. Sukhanov1, L.B. Arkhangelsky2}

1ASK-MSC Company, Moscow, 117246, Russia, dr.sukhanov@ mail.ru 2President Union Smiths, Moscow, 111033, Russia, tigram.korolev@ mail.ru

\section{ABSTRACT}

Considered the nature of the change of the morphology of excess carbides in Damascus steel (Wootz), depending on the degree of supercooling of the melt, heat treatment and plastic deformation. Discovered that some of blades Damascus steel has an unusual nature of origin of the excess cementite, which different from the redundant phases of secondary cementite, cementite of ledeburite and primary cementite in iron-carbon alloys. It is revealed that the morphological features of separate particles of cementite in Damascus steels lies in the abnormal size of excess carbides having the shape of irregular prisms. Considered three hypotheses for the formation of excess cementite in the form of faceted prismatic of excess carbides. The first hypothesis is based on thermal fission of cementite of a few isolated grains. The second hypothesis is based on the process of fragmentation cementite during deformation to the separate the pieces. The third hypothesis is based on the transformation of metastable cementite in the stable of angular eutectic carbide. It is shown that the angular carbides are formed within the original metastable colony ledeburite, so they are called "eutectic carbide". It is established that high-purity white cast iron is converted into of Damascus steel during isothermal soaking at the annealing. It was revealed that some of blades Damascus steel ledeburite class do not contain in its microstructure of crushed ledeburite. It is shown that the pattern of carbide heterogeneity of Damascus steel consists entirely of angular eutectic carbides. Believe that Damascus steel refers to non-heat-resistant steel of ledeburite class, which have similar structural characteristics with semi-heat-resistant die steel or heat-resistant high speed steel, differing from them only in the nature of excess carbide phase. 


\section{Introduction}

In the classification of Tool steel according to Prof. Geller (1968) was no place for the legendary Damascus steel (Wootz). Wootz removed from modern metallurgy. A relic of the past, which have not found application in the present. The legend for which no future! Why did this happen? Is it possible the triumphant return of Damascus steel (Wootz) on the highest step of the podium? We believe that this is possible. Studying articles Gayev (1965), Tavadze et al (1984), Schastlivtsev et al (2013), Sherby and
Wadsworth (1985), Verhoeven et al (1996), Barnett et al (2009), in which researchers samples of ancient blades from Damascus steel. We concluded that of part of excess cementite has an unusual nature of origin differing from of the excess phases of secondary cementite, ledeburite and primary cementite. The morphological features of excess cementite have the shape of irregular prisms, which from our point of view, more similar in morphology with eutectic carbides of steels ledeburite class (Fig. 1, a-b).
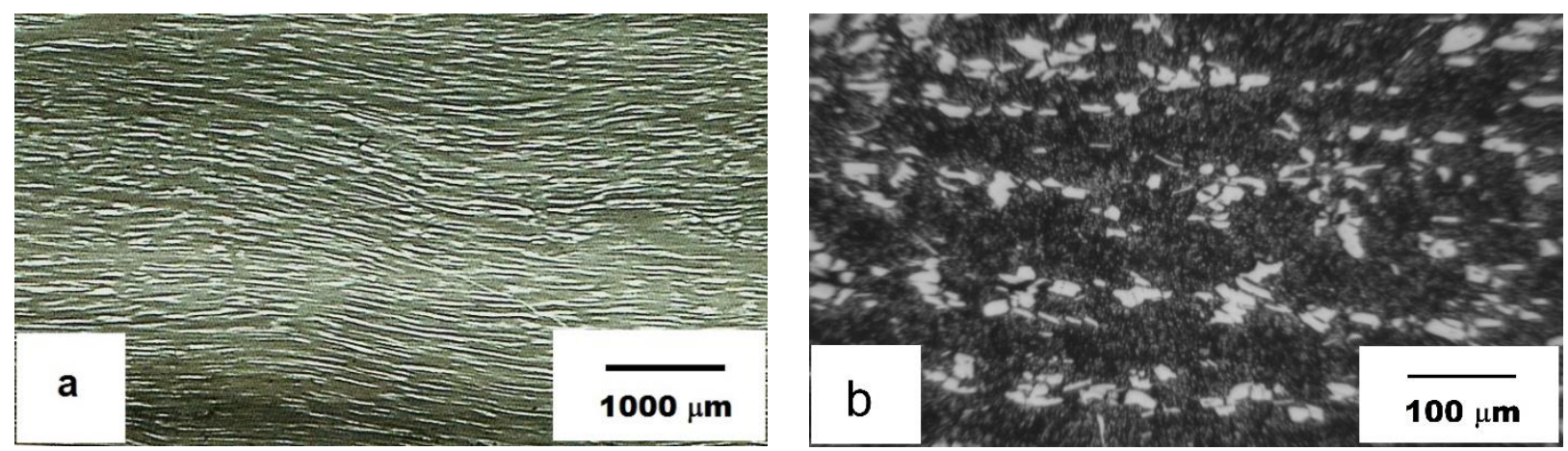

Fig. 1. Macrostructure (a) and microstructure (b) Damascus steel (Wootz).

Extreme operating conditions of the cutting tool under dynamic loads can match Damascus steel in which the carbon content is the same as in white cast iron. The aim of this work is the study of morphological signs of excess carbide phase in Damascus steel, after the process of smelting, heat treatment and plastic deformation. The mechanism of formation of faceted carbides in Damascus steel is still not known. Question about the transformation of excess cementite in the angular carbides is one of the most interesting and important in the analyzed problem. This has not only scientific but also practical significance. Knowing the answer to this question, it is possible to control the entire range of mechanical and physical properties of Damascus steel (Wootz).

\section{Materials and Methods}

The object of the research was chosen the high carbon alloys after melting, which in the structure have ledeburite phase. The chemical composition of the alloys is presented in table 1 . The chemical composition of the alloy controlled with the help of optical emission spectrometer ARL 3460 type. Phase analysis was performed on $\mathrm{x}$ ray diffractometer $A R L$ X'TRA.

In the marking of high-speed steel P6M5 letters and numbers mean the following: $P$ is rapid; 6 is the average tungsten weight fraction (5.8 wt.\%); $\mathrm{M}$ is molybdenum; 5 is the average molybdenum weight fraction (4.7 wt.\%). Marking die steels $\mathrm{X} 12$ means the following: $\mathrm{X}$ is chrome; 12 is the average chrome weight fraction (11.85 wt.\%). In the marking of Damascus steel BU22A letters

and numbers mean the following: $\mathrm{BU}$ is Bulat (Damascus steel) containing not more than $0.1 \%$ manganese and silicon (each individually); 22 is the average carbon weight fraction (2.25 wt.\%); A is a high-quality alloy containing not more than $0.03 \%$ sulphur and phosphorus (each individually).

Group of tool steels, in particular steels P6M5 and X12 belong to the ledeburite class. A distinctive structural characteristic of these steels is a ledeburite component. The structure of die steels ledeburite class is shown in Fig. 2. In the structure of steel $\mathrm{X} 12$ is present after the melting of the metastable ledeburite, which is located at the grain boundaries of austenite. Part ledeburite includes a carbide phase $(\mathrm{Fe}, \mathrm{Cr})_{3} \mathrm{C}$, 
D.A. Sukhanov and ASK-MSC Company, IRJMSA, 2017; 1:6

which is in the process of forging transformed the hexagonal eutectic carbides of type (Fe, $\mathrm{Cr}) 7 \mathrm{C}_{3}$. At the long isothermal annealing, the eutectic carbides are transformed into chromium carbides $\mathrm{Cr}_{7} \mathrm{C}_{3}$. The newly formed chromium carbides are crucial to a performance

TABLE 1. Test steels ledeburite class chemical composition.

\begin{tabular}{|c|c|c|c|c|c|c|c|c|c|}
\hline \multirow{2}{*}{ Alloys } & \multicolumn{7}{|c|}{ The contents of chemical elements, \% } \\
\cline { 2 - 10 } & $\mathrm{C}$ & $\mathrm{Si}$ & $\mathrm{Mn}$ & $\mathrm{P}$ & $\mathrm{S}$ & $\mathrm{Cr}$ & $\mathrm{V}$ & $\mathrm{Mo}$ & $\mathrm{W}$ \\
\hline P6M5 & 0,82 & 0,51 & 0,25 & $\begin{array}{c}0,02 \\
0\end{array}$ & $\begin{array}{c}0,00 \\
6\end{array}$ & 3,60 & 1,8 & 4,7 & 5,8 \\
\hline X12 & 1,95 & 0,30 & 0,24 & $\begin{array}{c}0,02 \\
4\end{array}$ & $\begin{array}{c}0,02 \\
3\end{array}$ & $\begin{array}{c}11,8 \\
5\end{array}$ & -- & -- & -- \\
\hline BU22A & 2,25 & $\begin{array}{c}0,06 \\
5\end{array}$ & $\begin{array}{c}0,02 \\
4\end{array}$ & $\begin{array}{c}0,00 \\
2\end{array}$ & $\begin{array}{c}0,00 \\
4\end{array}$ & -- & -- & -- & -- \\
\hline
\end{tabular}

tool. In this regard, is of great interest, study of the structure of the alloy BU22A, which in its composition is a white high-purity cast iron.

Structural investigations were carried out using an optical microscope of a series METAM RV-
21-2 in the zoom range from 50 to 1100 fold. Deeper structural investigations were carried out on scanning electron microscope CarlZeiss EV050 XVP using microanalyzer EDS X-Act.

\begin{tabular}{|c|c|c|}
\hline \multicolumn{3}{|c|}{ DIE STEEL LEDEBURITE CLASS (X12) } \\
\hline MELTING & FORGING & ANNEALING \\
\hline $\begin{array}{c}\text { Matrix: AUSTENITE } \\
\text { Excess phase: LEDEBURITE }\end{array}$ & $\begin{array}{c}\text { Matrix: SORBITE } \\
\text { Excess phase: CARBIDES }\end{array}$ & $\begin{array}{c}\text { Matrix: FERRITE } \\
\text { Excess phase: CARBIDES }\end{array}$ \\
\hline $\begin{array}{c}\text { Zonal segregation of } \\
\text { carbon }\end{array}$ & $\begin{array}{l}\text { The formation of } \\
\text { eutectic carbides }\end{array}$ & $\begin{array}{l}\text { The growth of } \\
\text { excess carbides }\end{array}$ \\
\hline $20 \mu \mathrm{m}$ & & of \\
\hline
\end{tabular}

Fig. 2. Structure of Die steel ledeburite class (X12) after melting, forging and annealing.

\section{Discussion and Results}

Advanced structure of Damascus steel (Wootz) before forging is a high-purity of iron matrix, with excess phase of metastable ledeburite, without Widmanstatten cementite. The purity of matrix during deformation plays a decisive role. The modern level of metallurgical production does not yet allow large scale to obtain large-sized products from high-carbon alloy with a minimum 
amount of impurities (hundredths of a percent). Only iron and carbon!

In the modern sense of the purity alloys does not exclude the presence of residues of deoxidation with manganese or silicon. The presence in alloys of manganese more than $0.2 \% \mathrm{Mn}$ reduces the growth of dendrites of austenite during solidification of the melt, changes the chemistry of (1952), the graphitization occur by the dissolution of metastable cementite in solid solution of austenite with subsequent nucleation and growth of graphite centers.

In the book, Prof. Golikov (1958) indicated that the most effective way to purity of the steels from impurities is the zonal segregation. Development zonal segregation in the ingot steel contributes to the boiling during melting. Boiling steel is substantially free of non-metallic inclusions and deoxidation products $(\mathrm{Si}<0,07 \%)$. Additive of iron oxide $(\mathrm{FeO})$ in smelting improves ductility and zonal segregation of carbon, as indicated in the work of Anosov (1841). The modification of the charge iron oxide binds harmful impurities, which are removed together with the slag.

Damascus steel (BU22A) has been received melting in the crucible at temperature of $1500^{\circ} \mathrm{C}$ with isothermal exposure for 20 minutes until complete melting of the alloy (crucible steel). At the temperature of $1200^{\circ} \mathrm{C}$ alloy was aged for 10 hours. The result isothermal holding between liquidus and solidus is formed of large dendrites of austenite with depleted carbon content $(C<$ carbide, perlite stabilizes at the high-temperature annealing. The silicon about $0.2 \% \mathrm{Si}$ creates centers of graphitization. When supercooling of the melt forms a metastable cementite which capable at the heating to disintegrate with the formation of graphite and austenite. As noted by Prof. Bogachev

$0,8 \%)$. Interdendritic areas is enriched of the carbon until the eutectic content. A similar effect was noted in the work of Prof. Gayev (1965). After slow cooling with the furnace, the alloy matrix BU22A acquires a coarse structure of pearlite with interlamellar spacing of about $0.6-1.0 \square \mathrm{m}$. Noticeable changes occur in the morphology of the excess carbide phase. In the plane of the thin section observed coarse conglomerates carbide formations of about $10.0-30.0 \square \mathrm{m}$. Metallographic signs allowed to identify them as a metastable ledeburite (Fig. 3). The Characteristic morphological feature of the metastable ledeburite is that it compared to lamellar and cell ledeburite white cast iron contains in its structure a reduced amount of micropores and has not pronounced layering. It is in composition not quite ledeburite, but still not quite the eutectic carbide. We described for alloy BU22A of the transformation metastable ledeburite in the eutectic carbides in articles (Sukhanov, Arkhangel'ski, 2016; Sukhanov, Arkhangelsky, Plotnikova, Belousova, 2016; Sukhanov, Arkhangelskiy, Plotnikova, 2016; Sukhanov, Plotnikova, 2016).

\begin{tabular}{|c|c|c|}
\hline \multicolumn{3}{|c|}{ DAMASCUS STEEL LEDEBURITE CLASS (BU22A) } \\
\hline MELTING & FORGING & ANNEALING \\
\hline $\begin{array}{c}\text { Matrix: PEARLITE } \\
\text { Excess phase: LEDEBURITE }\end{array}$ & $\begin{array}{c}\text { Matrix: SORBITE } \\
\text { Excess phase: CARBIDES }\end{array}$ & $\begin{array}{c}\text { Matrix: FERRITE } \\
\text { Excess phase: CARBIDES }\end{array}$ \\
\hline $\begin{array}{c}\text { Zonal segregation of } \\
\text { carbon }\end{array}$ & $\begin{array}{l}\text { The formation of } \\
\text { eutectic carbides }\end{array}$ & $\begin{array}{l}\text { The growth of } \\
\text { excess carbides }\end{array}$ \\
\hline $20 \mu \mathrm{m}$ & 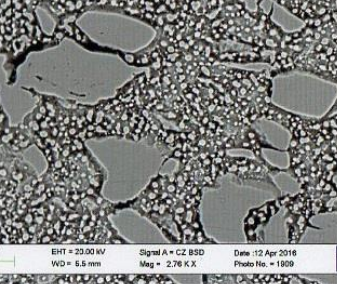 & $\overline{20 \mu \mathrm{m}}$ \\
\hline
\end{tabular}

Fig. 3. Structure of Damascus steel ledeburite class type BU22A after melting, forging and annealing. 
Deformation of the cast alloy BU22A was performed using forging to the temperature range from $8500 \mathrm{C}$ to $650 \mathrm{OC}$. Metastable ledeburite is under the influence of the normal stress austenitic matrix and shear stress deformation. Around metastable carbides, accumulate defects such as dislocations. When the dislocation density reaches a critical value in a metastable ledeburite occur phase change, resulting in less stable carbides ledeburite transform more stable eutectic carbides (Fig.3). The transformation of metastable ledeburite in the faceted carbides angular shape is that a new phase is formed inside the source phases. The growth carbides angular shape happens migration of interphase boundaries. In the future, the growth of excess carbides is a diffusion redistribution of the components between the carbide and solid solution of austenite. The migration of interphase boundaries in the process of transformation leads to the separation of excess carbides angular shape.

The mechanism of formation of faceted carbides angular shape in Damascus steel (Wootz) is still not clear. From our point of view, there are three hypotheses that explain why, under certain conditions, the cementite becomes angular shape (Fig. 4, a) and unevenly distributed within the volume of the pearlite matrix (Fig. $4, \mathrm{~b}$ ).
The first hypothesis is based on the process of termal division of the plates of cementite on the isolated single grain. Process of thermal division of cementite for steel ledeburite class has been studied in the work of Prof. Bunin et al (1969). The alloy BU22A is becomes Damascus steel during isothermal soaking at the annealing. Prolonged annealing leads not only to thermal division of cementite plates, but also to their faceting. In the annealing process on the surface of the plate's cementite in the junctions between the grains of boundaries of austenite appear protrusions in the form of spikes. The growth of spikes of a long of grain boundaries austenite occur due to increased speed of diffusion of carbon. In the process of isothermal exposure at the annealing of cementite between of spikes of become thinner. In these places occur to the divide of cementite into parts. As a result, between the individual particles of cementite formed grains boundaries of austenite. Part of the excess carbides has an irregular trigonal-prismatic morphology. New angular carbides is formed within the original colony metastable ledeburite, so they are called "eutectic carbides", by analogy with a faceted angular carbides in alloy steels ledeburite class.
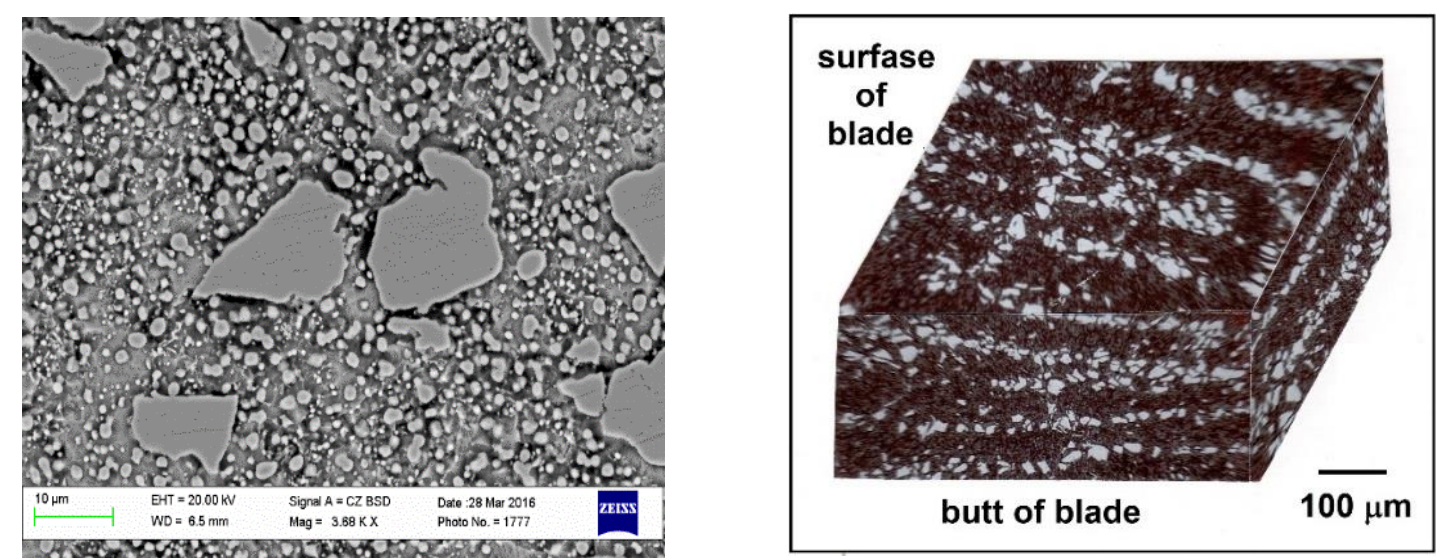

Fig.4. Morphology of carbides in Damascus steel (BU22A): a - electron microscope (eutectic carbides); $b$ - diagram of the structure of blade Damascus steel.

The second hypothesis is based on the process of fragmentation cementite during deformation to the separate the pieces. The traditional view on the formation of angular carbides are described in detail in book Prof. Geller (1968). It is assumed that the anomalously large angular carbides are formed because of the fragmentation of metastable ledeburite in the process of plastic deformation into separate parts (fragments). The greater the degree of deformation during forging, the stronger destroyed clusters of carbides. Crushing carbide conglomerates occur in places of a congestion of dislocations. It can 
be assumed that these of angular carbides are fragments of the ledeburite eutectic. However, we have convincingly shown that the structure of Damascus steel BU22A does not contain crushed ledeburite. This statement was shown to us in articles (Sukhanov, 2014; Sukhanov, Arkhangelsky, Plotnikova, Belousova, 2016; Sukhanov, Arkhangelskiy, Plotnikova, 2016; Sukhanov, Plotnikova, 2016; Sukhanov, Arkhangelskiy, Plotnikova, 2017).

The basis of the third hypothesis laid the conclusion of Prof. Nizhnikovskaya (1982) that the plasticity of white cast irons, possible as a result to the transformation of excess carbide. The essence of the hypothesis is recrystallization of metastable ledeburite in the process of plastic deformation in a stable phase of the eutectic carbide angular morphology. Non-alloy eutectic carbide is formed by the restructuring of the lattice of intermediate metastable cementite carbides in which the carbon atoms are packed in a trigonal prismatic complex, which gives of the faceted eutectic carbides.

High-temperature annealing forged Damascus steel (BU22A) at a temperature of $1000^{\circ} \mathrm{C}$ and isothermal exposure for 15 minutes showed that is occurs growth of the eutectic cementite due to the secondary particles of cementite. The process of coalescence of the eutectic carbides at high-temperature annealing is consist to the diffusion transfer of carbon atoms through the solid solution of austenite. The growth of eutectic cementite is carried out by the migration of interphase boundaries. Eutectic carbides angular forms grow at the expense of smaller particles of secondary cementite. The process of coalescence of the eutectic carbides increases with long-term high temperature exposures. As a result, is occur the decarburization of the matrix due to the abnormal growth of eutectic carbides (Fig. 3). A similar process was observed in articles Prof. Gayev (1965) and Prof. Schastlivtsev et al (2013). It should be noted that in the process of coalescence, eutectic carbides retain angular form whereas secondary excess carbides, usually spheroidization. The process of coalescence of the eutectic carbides is irreversible. During high-temperature, annealing forged Damascus steel is terminated the process of the formation of abnormally large eutectic carbides. In the history of tool steels ledeburite class, most attention paid to the issue of the destruction of the ledeburite network carbides. The negative impact of ledeburite mesh for durability and long tool life is obvious. Conversion methods may be different. Among experts, there is no consensus. The prevailing view about the fragmentation of ledeburite network carbides during deformation, described in the articles (Bogachev, 1952; Golikov, 1958; Geller, 1968). During crushing of ledeburite network carbides formed fragments with sharp edges (angular carbides). However, in the articles (Taran, Nizhnikovskaya, Mironova, 1974; Nizhnikovskaya, 1982) dominated by the opposite opinion. Angular carbides are formed during high temperature isothermal annealing. Metastable ledeburite because of carbides of the type $\mathrm{M}_{6} \mathrm{C}$ and $\mathrm{M}_{3} \mathrm{C}$ thermally crushed and transformed in the eutectic carbides type $\mathrm{MC}, \mathrm{M}_{2} \mathrm{C}$ and $\mathrm{M}_{7} \mathrm{C}_{3}$ with hexagonal structure. The morphological similarity of the angular carbides in the alloy BU22A with hexagonal carbides of Die steel X12 and High-speed steel P6M5 suggests about the same processes of formation of angular carbides (Fig.5).

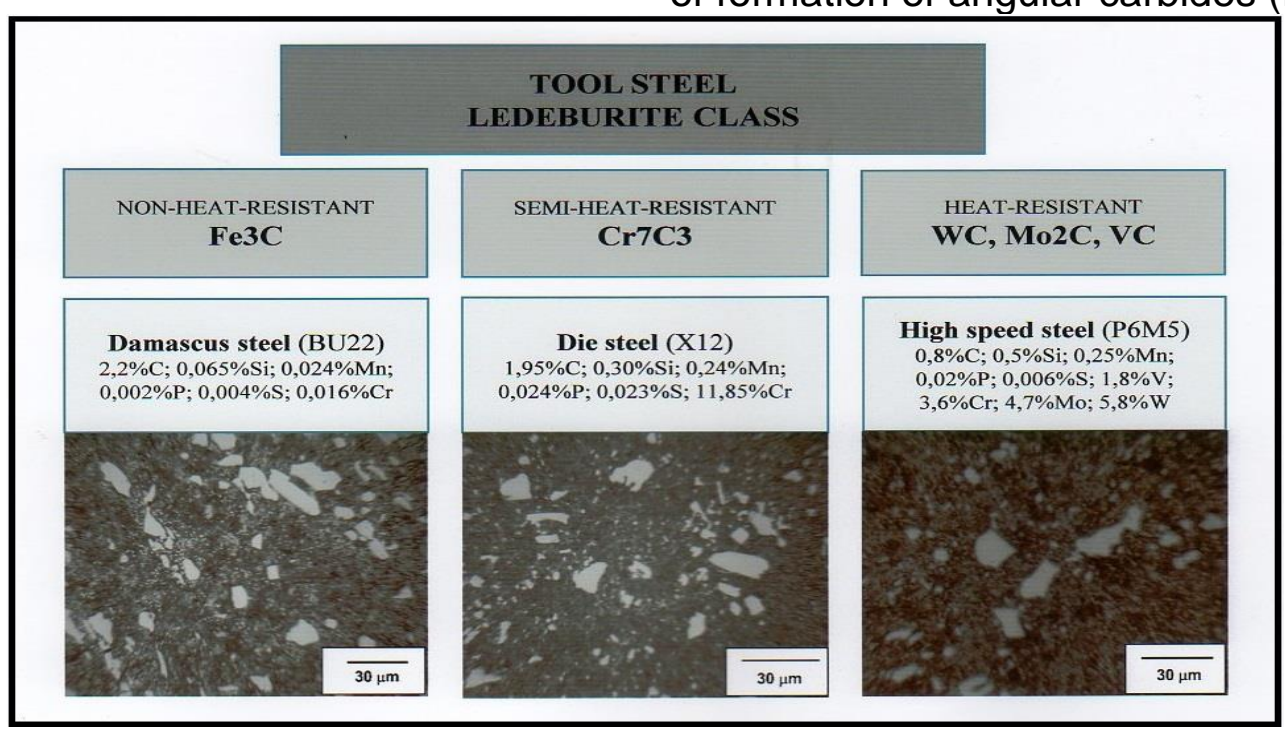

Http://escipub.com/international-research-journal-of-materials-sciences-and-applications/ 
Fig. 5. Classification of Tool steels ledeburite class of heat resistance of the excess carbides.

The above points to the emergence in the structure of Damascus steel BU22A new carbide with hexagonal close-packed lattice of the type $\mathrm{Fe}_{7} \mathrm{C}_{3}$, or a special form of cementite with an orthorhombic close-packed lattice of the type $\mathrm{Fe}_{3} \mathrm{C}$. Alloys, having in its structure hexagonal carbides $\mathrm{Fe}_{7} \mathrm{C}_{3}$ must have a lower magnetization, which corresponds to a lower relative concentration of iron in these carbides compared to the cementite. However, such experimental work I have never met.

What is this angular carbide in Damascus steel (Wootz)? To answer this question, we determined the phase composition of carbides angular shape. Method detail described in our article. Analysis of diffraction patterns showed that the main phases in BU22A are ferrite $(\alpha-F e)$ and cementite $\left(\mathrm{Fe}_{3} \mathrm{C}\right)$. Because of the interference of the overlapping lines of the secondary cementite is not possible to determine the exact composition of angular carbides. At this stage of research it is possible to speak only about what we are faced with a special morphology of cementite. Eutectic carbides in Damascus steel BU22A are cementite $\left(\mathrm{Fe}_{3} \mathrm{C}\right)$, which has low heat resistance. Therefore, follows to consider Damascus steel (Wootz) as non-heat-resistant Tool steel ledeburite class, in which microstructure similar with semi-heat-resistant Die steel (X12) or heat-resistant High-speed steel (P6M5), differing from them only in the nature of excess carbide phase (Fig. 5).

\section{Conclusions}

Carbide phase in Damascus steel (Wootz) has unusual origins. The morphological features of carbide phase Wootz, is the abnormal size of faceted particles of cementite having the shape of an irregular prism. Carbides angular shape can be formed in the process three competing

\section{References}

Anosov, P. P. (1841) Bulats. Mining journal, 2, 157-317. (In Russian)

Barnett, M. R., Sullivan, A., Balasubramaniam, R. (2009) Electron backscattering diffraction analysis of an ancient wootz steel blade from central India. Materials Characterization, 60 , 252-260. mechanisms (hypothesis). The first hypothesis is based on thermal fission of cementite of a few isolated grains. The second hypothesis is based on the process of fragmentation cementite during deformation to the separate the pieces. The third hypothesis is based on the transformation of metastable cementite in the stable of angular eutectic carbide. Generally, all three mechanisms are present in the formation of faceted carbides.

By nature Damascus steel ledeburite class type BU22A similar to High-speed steel type P6M5 and Die steel type $X 12$, because in it is occur the same transformation at the melting and thermomechanical processing. Damascus steel (Wootz) containing about $1.9 . . .2 .3 \%$ carbon are the Tool steels ledeburite class. The cast form the structure of the Damascus steel (Wootz) represents a major dendrites, in the interstices of which is found of metastable ledeburite. When forging is, occur transformation of metastable ledeburite in eutectic carbides angular shape. In the annealed condition the structure of Damascus steel (Wootz) is ferritic matrix with unevenly spaced in it large angular eutectic carbides with a size to $30.0 \mu \mathrm{m}$.

Pattern carbide inhomogeneity in the alloy BU22A consists entirely of angular eutectic carbides having an irregular trigonal-prismatic morphology. The angular carbides are formed within the original metastable colony ledeburite, so they are called "eutectic carbide". Similar morphology of the carbides is observed in Tool steels ledeburite class. Eutectic carbides in BU22A is a cementite, which has low heat resistance. Believe that Damascus steel (Wootz) refers to non-heat-resistant steel of ledeburite class, which have similar structural characteristics with semi-heat-resistant die steel or heat-resistant high speed steel, differing from them only in the nature of excess carbide phase.

Bogachev, I. N. (1952) Metallography of Cast Iron. Mashgiz, Moscow.

Bunin, K. P., Baranov, A. A., Evsyukov, M. F., Pritomanova, M. I. (1969) Mechanism of Division of Crystals of Cementite in Annealing Spheroidizing. Metal Science and Heat Treatment, 6, 19 - 23. (In Russian)

http://dx.doi.org/10.1016/i.matchar.2008.10.004 
Gaev, I. S. (1965) Bulat and contemporary iron-carbon alloys. Metal Science and Heat Treatment, 9, 17-24. (In Russian)

Geller, Yu. A. (1968) Tool steels. Metallurgy, Moscow.

Golikov, I. N. (1958) Dendritic Liquation in Steel. Metallurgizdat, Moscow.

Nizhnikovskaya, P. F. (1982) Carbide Transformations in Eutectic Iron-Carbon Alloys. Metals, 6, 105-110. (In Russian)

Schastlivtsev, V. M., Urtsev, V. N., Shmakov, A. V., et al (2013) Structure of Bulat. FMM, 114(7), 650-657. http://dx.doi.org/10.1007/s11015-016-0178-x

Sherby, O. D., Wadsworth, J. (1985) Damascus steel. Scientific American, 252(2), 112-120. http://dx.doi.org/10.1038/scientificamerican0285-112

Sukhanov, D. A. (2014) Damask steel - unalloyed carbide class steel. Metallurgist, 58, 149-153. http://dx.doi.org/ 10.1007/s11015-014-9884-4

Sukhanov, D. A., Arkhangel,ski, L. B. (2016) Damascus steel microstructure. Metallurgist, 59, 818-822. http://dx.doi.org/10.1007/s11015-016-0178-x

Sukhanov, D. A., Arkhangelsky, L. B., Plotnikova, N. V., Belousova, N. S. (2016) Morphology of Excess Carbides Damascus Steel. Journal of Materials Science Research, 5(3), 59-65. http://dx.doi.org/10.5539/jmsr.v5n3p59

Sukhanov, D. A., Arkhangelskiy, L. B., Plotnikova, N. V. (2016) The Morphology of the Carbides in High-Carbon Alloys such as Damascus steel. Metal Working and Material Science, 4(73), 43-51. http://dx.doi.org/10.17212/1994-6309-2016-4-43-51

Sukhanov, D. A., Plotnikova, N. V. (2016) Wootz: Cast Iron or Steel? Materials Sciences and Applications, 7, 792-802. http://dx.doi.org/10.4236/msa.2016/711061

Sukhanov D.A., Arkhangelskiy L.B., Plotnikova N.V. (2017) Nature of Angular Carbides in Damascus steel. Metallurgist, 61, 4046. http://dx.doi.org/10.1007/s11015-017-0451-7

Taran, Yu. N., Nizhnikovskaya, P. F., Mironova, E. N. (1974) Nature of Angular Carbides in High-Speed steel. Metal Science and Heat Treatment, 2, 10 -13. (In Russian)

Tavadze, F. N., Amaglobeli, V. G., Inanishvili, G. V., Eterashvili, T. V. (1984) Electron Microscopic Studies of Bulat. Bulletin of the Academy of Sciences of the Georgian SSR, 113(3), 601-604. (In Russian)

Verhoeven, J. D., Pendray, A. H., Gibson, E. D. (1996) Wootz Damascus steel Blades. Materials Characterization, 37, 9-22. http://dx.doi.org/10.1016/s10445803(96)00019-8 